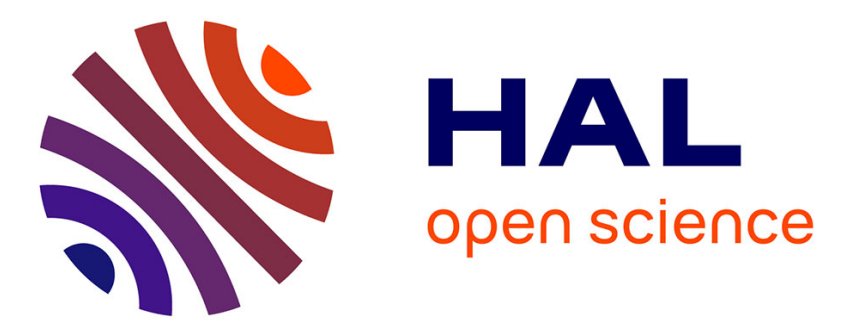

\title{
Identification of liver protein targets modified by tienilic acid metabolites using a two-dimensional Western blot-mass spectrometry approach
}

\author{
Ruth Menque Methogo, Patrick M. Dansette, Klaus Klarskov
}

\section{- To cite this version:}

Ruth Menque Methogo, Patrick M. Dansette, Klaus Klarskov. Identification of liver protein targets modified by tienilic acid metabolites using a two-dimensional Western blot-mass spectrometry approach. International Journal of Mass Spectrometry, 2007, 268 (2-3), pp.284-295. 10.1016/j.ijms.2007.06.002 . hal-00192244

\section{HAL Id: hal-00192244 \\ https://hal.science/hal-00192244}

Submitted on 27 Nov 2007

HAL is a multi-disciplinary open access archive for the deposit and dissemination of scientific research documents, whether they are published or not. The documents may come from teaching and research institutions in France or abroad, or from public or private research centers.
L'archive ouverte pluridisciplinaire HAL, est destinée au dépôt et à la diffusion de documents scientifiques de niveau recherche, publiés ou non, émanant des établissements d'enseignement et de recherche français ou étrangers, des laboratoires publics ou privés. 
Identification of liver protein targets modified covalently by tienilic acid metabolites using a two dimensional Western blot-mass spectrometry approach

\author{
Ruth Menque Methogo ${ }^{\mathrm{a}}$, Patrick M. Dansette ${ }^{\mathrm{b}}$ and Klaus Klarskov ${ }^{\mathrm{a}^{*}}$
}

a. Department of Pharmacology, Faculty of Medicine, 3001 12e Avenue Nord, Université de Sherbrooke, Sherbrooke J1H 5N4, Quebec, Canada. klaus.klarskov@usherbrooke.ca

b. Université Paris-Descartes, CNRS UMR 8601, Paris, France. Patrick.Dansette@univ-paris5.fr

*Corresponding author. Department of Pharmacology, Faculty of Medicine, 3001 12e Avenue Nord, Université de Sherbrooke, Sherbrooke J1H 5N4, Quebec, Canada. Tel. 1819-820-6868 ext. 1-5490 Fax 1-819-564 5400. Email: klaus.klarskov@usherbrooke.ca 


\begin{abstract}
A combined approach based on two dimensional electrophoresis-immuno blotting and nanoliquid chromatography coupled on-line with electrospray ionization mass spectrometry (nLC-MS/MS) was used to identify proteins modified by a reactive intermediate of tienilic acid (TA). Liver homogenates from rats exposed to TA were fractionated using ultra centrifugation; four fractions were obtained and subjected to 2D electrophoresis. After transfer to PVDF membranes, modified proteins were visualized after India ink staining, using an anti-serum raised against TA and ECL detection. Immuno-reactive spots were localized on the PVDF membrane by superposition of the ECL image, protein spots of interest were excised, digested on the membrane with trypsin followed by nLC-MS/MS analysis and protein identification. A total of fifteen proteins were identified as likely targets modified by a TA reactive metabolite. These include selenium binding protein 2, senescence marker protein SMP-30, adenosine kinase, Acy1 protein, adenosylhomocysteinase, capping protein (actin filament), protein disulfide isomerise, fumarylacetoacetase, arginase chain A, ketohexokinase, proteasome endopeptidase complex, triosephophate isomerase, superoxide dismutase, dna-type molecular chaperone hsc 73 and malate dehydrogenase.
\end{abstract}

Keywords. 2D immuno blotting, tienilic acid, nanoliquid chromatography-electrospray ionization mass spectrometry, on-membrane digestion, protein modification. 


\subsection{Introduction}

Drug induced autoimmune hepatitis, characterized by hepatitic, cholestatic, or miscellaneous clinical features belongs to some of the most severe adverse drug reactions. Common to these reactions are the involvement of an improper immune response that is directed toward the host's liver. Studies in the past indicate that the uricosuric diuretic agent, tienilic acid (also named, Ticrynafen, Selacryn, Diflurex; 2,3dichloro-4-(2-thienylcarbonyl) phenoxyacetic acid) (TA) causes drug inducedautoimmune hepatitis in certain persons. As a consequence, TA was withdrawn from clinical use in the United States in the early eighties [1] and in France in 1992. Although several mechanisms may be involved, the current understanding of drug inducedautoimmune diseases is based on two interdependent complementary working hypotheses e.g. the "Hapten" and the "Danger" hypothesis [2-4]. Of importance for both hypotheses is the requirement for metabolic transformation of the drug to a reactive metabolite(s), resulting in two different but essential outcomes. The first involves covalent modification of cellular macromolecules by reactive metabolites that after intra cellular processing lead to modified peptides being presented as antigens to the immune system, probably via the MHC processing system. In addition, it seems likely that in order to trigger the immune response some kind of cellular stress should be present. This assumption is based on the fact that immune mediated adverse drug reactions are dramatically increased in persons concomitantly infected with a virus or suffering from other ailments [5]. Metabolic activation of a drug causing either direct or indirect up-regulation of cellular stress proteins could be involved. Alternatively, modification of essential or specific stress proteins could be an important factor resulting in cellular stress. Initial phases of 
TA toxicity are believed to be due to metabolic activation by CYP450 2C9 to a reactive metabolite that can deplete glutathione (GSH) and covalently bind to certain proteins. Analysis of sera obtained from patients suffering from liver damage following TA exposure revealed the presence of highly specific anti-liver and kidney microsomal (antiLKM2) autoantibodies [6] known to specifically recognize CYP450 2C9 in humans $[7,8]$ and the corresponding isoform $2 \mathrm{C} 11$ in rats[9]. Subsequent studies have revealed that tienilic acid undergoes a selective CYP450 2C9-mediated bioactivation on its thiophene ring, resulting in the formation of a reactive intermediate that covalently modifies the enzyme [10] despite that a stable peptide conjugate has never characterized [11,12]. A relatively limited number of proteins appear to be modified by TA metabolites in both human and rat liver microsomes $[9,10,13,14]$. In contrast, the isomer of TA has been shown to be metabolized into a thiophene sulfoxide, leading to modification of many more proteins $[9,15,16]$. In addition, TA could be metabolized by other until now unknown or known enzymes without suicide inactivation resulting in protein modification but this has yet to be confirmed. For a number of carboxylic acid containing drugs, glucuronidation has been proposed to be a major metabolic pathway that potentially could increase the reactivity of certain drugs resulting in covalent modification of proteins [17]. The formation of reactive metabolites by this pathway and covalent protein modification has previously been demonstrated for numerous non steroidal anti-inflammatory drugs including ibuprofen [18], ketoprofen [19] and zomepirac [20] as well as for other drugs like mycophenolic acid [21], clofibric acid [20], diflunisal [22,23] and valproic acid [20]. Despite that proteins have been found to be covalently modified by reactive drug metabolites both in vivo and in vitro, only a 
relatively small number have until know been identified. So far, proteomics approaches based on mass spectrometry and separation techniques suitable for this type of analysis, have only been used in a few cases $[21,24,25]$. Recently, we developed a new approach allowing the mass spectrometric analysis of immuno-reactive protein spots obtained from the membrane used for Western blotting and thus to identify post translationally modified proteins including those modified by reactive drug metabolites [26]. Except for CYP P450 2C9 and the 2C11 variant in rats, a comprehensive knowledge about what cellular proteins are covalently modified after exposure to TA is still lacking. The aim of the present study was to take advantage of a proteome approach exploiting pre-fractionation of cellular organelles and 2D Western blotting in combination with mass spectrometry to identify the comprehensive suite of modified rat liver proteins.

\subsection{Experimental}

\subsection{Animals and sample preparation}

The experimental protocol was approved by the institution animal care unit. Wistar rats ( 200-250 g) were allowed to rest for one week before exposure to TA. Rats having received an injection intra-peritoneal of TA (100 $\mathrm{mg}$ of drug per $\mathrm{kg}$ of weight) or saline (control) were sacrificed at 4 and 24 hours respectively. The livers were immediately removed, sliced into small pieces with a clean scalpel and homogenized at 4.C in $7 \mathrm{ml}$ of buffer (10mM Tris-HCl pH 7.5, $250 \mathrm{mM}$ sucrose, $20 \mu 1$ peptidase inhibitor cocktail) using a potter helm homogenizer with a loose pestle and 5-10 strokes per $1 \mathrm{~g}$ of liver. These procedures were repeated in two independent experiments.

\subsection{Enrichment of liver sub-cellular fractions by ultra-centrifugation.}


Rat liver homogenate was centrifuged at $600 \mathrm{x}$ g for $10 \mathrm{~min}$ to precipitate cell nuclei and cellular debris. The supernatant was collected, transferred into ultracentrifuge tubes and further centrifuged at $15.000 \mathrm{x}$ g for $5 \mathrm{~min}$. The precipitate represented fraction I. Centrifugation of the supernatant at $100.000 \mathrm{x} \mathrm{g}$ for $60 \mathrm{~min}$ resulted in fraction II. The last ultracentrifugation at $100.000 \mathrm{x}$ g for 5 hours gave fraction III (precipitate) and fraction IV (supernatant). Centrifugations were performed at $4 \mathrm{IC}$ using a Sorvall RC 5B plus centrifuge (Mandel, ON, Canada) and the enriched sub-cellular fractions were stored at -20YC until further analysis. Protein concentrations in each step were estimated using the BCA assay (Pierce, Rockford, IL, US). Samples were dissolved in 10\% SDS and dilutions were made in $1 \%$ SDS prior to performing the assay as described by the manufacture.

\subsection{D Electrophoresis and protein staining.}

Protein 2D SDS-PAGE separations were performed in the first dimension by isoelectric focusing (IEF), using ReadyStrips (pH 3-10, 4-7 and 5.5-6.7, $11 \mathrm{~cm}$ long, Bio-Rad, Mississauga, ON, Canada). The ReadyStrips were rehydrated overnight at room temperature in $185 \mu \mathrm{l}$ of sample buffer (7M urea, $2 \mathrm{M}$ thiourea, $4 \%$ CHAPS, $100 \mathrm{mM}$ dithiothreitol, 1:50 volume of Biolyte $\mathrm{pH} \mathrm{3-10,} \mathrm{and} \mathrm{a} \mathrm{trace} \mathrm{of} \mathrm{bromophenol} \mathrm{blue)}$ containing $400 \mu \mathrm{g}$ of protein. The IEF was performed using a PROTEAN IEF Cell system (Bio-Rad) at $20^{\circ} \mathrm{C}$ with the following voltage gradient: $250 \mathrm{~V}$ over $20 \mathrm{~min}$, $250-8000 \mathrm{~V}$ over $2.5 \mathrm{~h}$, and then $8000 \mathrm{~V}$ until $20 \mathrm{kVh}$ was attained. After IEF, proteins were reduced for $10 \mathrm{~min}$ in equilibration buffer $(50 \mathrm{mM}$ Tris- $\mathrm{HCl} \mathrm{pH} 8.8$ containing $6 \mathrm{M}$ urea, 30\% glycerol and 2\% SDS, $100 \mathrm{mM} \mathrm{DTT}$ ) and alkylated for $10 \mathrm{~min}$ in the dark with iodoacetamide $(25 \mathrm{mg} / \mathrm{ml})$ in the same buffer but without DTT. Proteins were then separated by SDS-PAGE according to the method of Laemmli \{Laemmli, $1970 \# 197$ \} 
using $8-16 \%$ polyacrylamide gradient gels, for $150 \mathrm{~min}$ at $50 \mathrm{~mA} / \mathrm{gel}$. The gels were processed for Western blotting by transferring the proteins onto a PVDF membrane using a Trans-Blot SD semi-dry transfer cell (Bio-Rad, Mississauga, ON, Canada) for $55 \mathrm{~min}$ at $0.8 \mathrm{~mA} / \mathrm{cm}^{2}$ as described elsewhere $\{$ Mengue Methogo, $2005 \# 181$ \}.

\subsection{Immuno chemical detection.}

PVDF membranes were rinsed after electroblotting for 5 min first in $20 \% \mathrm{MeOH}$ and then in water prior to blocking for $10 \mathrm{~min}$ in $0.1 \%$ aqueous acetic acid containing $0.2 \%$ Tween 20. The proteins were stained in PBS containing 0.05\% (v/v) Tween 20, 1\% (v/v) acetic acid, and $0.1 \%(\mathrm{v} / \mathrm{v})$ Fount India ink until visible bands appeared (30 min to $12 \mathrm{~h}$ ). The PVDF membrane was then rinsed in wash buffer $(150 \mathrm{mM} \mathrm{NaCl}, 10 \mathrm{mM}$ Tris- $\mathrm{HCl}$ $\mathrm{pH} 7.6,0.05 \%$ Tween 20 ) and incubated overnight with the primary antiserum raised against TA (diluted 10.000x) in wash buffer. The antiserum was raised against BSA coupled to 5-chloro TA after activation of lysine residues with N-succinimidyl 3-(2pyridyldithio)-propionate, prepared as described previously \{Bonierbale, $1999 \# 196\}$. The anti-serum specificity was evaluated using competitive inhibition ELISA, lactoglobulin coupled as described for BSA and serial dilutions of TA, TA conjugated with mercaptoethanol, ethacrynic acid, 2-,3-dichlorophenoxy acetic acid and TA-isomer \{Bonierbale, $1999 \# 196$ \}. Following incubation with primary anti-serum, the PVDF membrane was washed $4 \times 5$ min in wash buffer before incubation for $1 \mathrm{~h}$ with monkey anti-rabbit IgG antibody (diluted 100.000x in wash buffer) conjugated with horseradish peroxidase. Following $4 \times 5$ min wash of the membrane in wash buffer, the ECL was developed as described by the manufacture for 1-2 min. In order to identify immunoreactive protein spots on the PVDF membrane, the transparency obtained after ECL 
detection was positioned on the membrane and pierced with a needle through the dark ECL spots leaving marks at the exact position. Membrane spots were then excised with a sharpened stainless steel tube and stored in Eppendorf tubes at $-20{ }^{\circ} \mathrm{C}$ until further use.

\subsection{On-membrane digestion.}

On membrane proteolysis was performed as previously described \{Mengue Methogo, $2005 \# 181$ \} except for following modifications: After reduction and alkylation with iodoacetamide membrane pieces were rinsed $4 \mathrm{x}$ with $400 \mu 150 \% \mathrm{ACN}$ in $100 \mathrm{mM}$ ammonium bicarbonate buffer (ABC) which was found to efficiently diminish tween-20 contaminants resulting in cleaner nLC-MS analyses. The solvent used for digestion consisted of $100 \mathrm{mM}$ ABC with $50 \%(\mathrm{v} / \mathrm{v})$ anhydrous amine free N,Ndimethylformamide (Alfa Cesar, MA, US) and was prepared immediately before use. In brief, prior to digestion proteins were reduced in $20 \mathrm{ul}$ of $100 \mathrm{mM} \mathrm{ABC}$ containing 5 _g/_1 DTT for 45 min at $37^{\circ} \mathrm{C}$. Carbamidomethylation was carried out in $20 \_1$ of 200 $\mathrm{mM}$ ABC containing 25 g/_ 1 iodoacetamide for $30 \mathrm{~min}$ in the dark. Following rinsing as described above, proteins were digested at $37{ }^{\circ} \mathrm{C}$ in $10 \_150 \mathrm{mM} \mathrm{ABC}$ containing $50 \%$ (v/v) DMF and $20 \mathrm{ng} / 1$ sequencing grade trypsin (Promega, USA) with occasional centrifugation to avoid concentration of DMF in the proteolysis buffer. After $3 \mathrm{~h}$ and the addition of $1 \mathrm{ul}$ of $5 \mathrm{M}$ urea, samples were incubated in an ultrasound bath for $2 \mathrm{~min}$, transferred to injection vials and dried in an Eppendorf Vacufuge Concentrator until completely dry (about $1 \mathrm{~h}$ ).

2.6 NanoLiquid chromatography-tandem mass spectrometry and data base searching. 
Peptides derived from "on-membrane" digestion were analyzed by nanoliquid chromatography coupled on-line with tandem electrospray ionization time-of-flight mass spectrometry (nLC-ESIMS/MS) consisting of a capillary liquid chromatograph with autosampler and a QTOF 2E mass spectrometer (Waters, MA, US). Tryptic peptides were dissolved in $14 \mu 1$ solvent A ( $1 \%$ acetonitrile, $1 \%$ isopropanol in $0.2 \%$ aqueous formic acid), loaded onto a $0.5 \mathrm{~mm}$ x $250 \mu \mathrm{m}$ I.D union packed with Magic C18 AQ(200 A, $5 \mu \mathrm{m}$; Michrom BioResources, Auburn, CA) and separated on a $100 \mu \mathrm{m}$ I.D x $10 \mathrm{~cm}$ capillary column packed with the same material. Each analysis was succeeded by injection of $10 \mu 150 \%$ (v/v) aqueous isopropanol followed by running a blank gradient, which efficiently eliminated contamination from sample carry over. The following linear gradient was used: from 10 to $70 \% \mathrm{~B}$ in $30 \mathrm{~min}$, to $90 \% \mathrm{~B}$ in $5 \mathrm{~min}$, and $10 \% \mathrm{~B}$ in $3 \mathrm{~min}$. The flow rate was split approximately $10 \mathrm{x}$ to $0.25-0.30 \mu \mathrm{l} / \mathrm{min}$. Survey scans were acquired at $1.9 \mathrm{~s} / \mathrm{scan}$. Depending on the charge state and intensity, doubly and triply charged parent ions were automatically selected for tandem mass spectrometry acquired at $1 \mathrm{~s} / \mathrm{scan}$ with a pre-set maximum of 5 scans per selected parent ion. Since singly charged parent ions were not selected for tandem mass spectrometry, the intensity threshold could be lowered to a minimum without the risk of spending acquisition time on ions from background, impurities and detergents. Although a low threshold is not a guaranty of acquiring MS/MS spectra useful for protein identification, it ensure selection of a maximum number of doubly and triply charged ions for MS/MS analysis, during the separation. Raw MS/MS spectra were processed automatically using the ProteinLynx software and converted into peak lists readable by the MASCOT search algorithm (http://www.matrixscience.com). The following search parameters were used: database; 
MSDB, species; Rattus, allowance of two missed tryptic cleavages, oxidation of methionine and cysteine carbamidomethylation, fragment mass tolerance; 0.25 Da.

\subsection{Results}

To achieve a survey and identify the suite of rat liver proteins modified by TA metabolites, rats were treated with either saline (control) or TA $(100 \mathrm{mg} / \mathrm{kg})$. After time intervals of 4 and 24 hours, the liver was isolated, homogenized and proteins were separated by 2D SDS PAGE. In preliminary experiments, proteins from total liver homogenates were focused in the first dimension from $\mathrm{pH} 3-10$ followed by separation in the second dimension on gradient polyacrylamide gels. Proteins modified covalently by TA metabolites were visualized on the corresponding Western blots with a polyclonal antiserum to TA [9]. A maximum of approximately 20 spots appeared to contain modified proteins, as judged by their immuno-reactivity. The spots were absent on Western blots of the control and appeared to increase in number from 4 to $24 \mathrm{~h}$ in two independent experiments. Although, it could not be entirely excluded that the increased intensity are due to variations in the sample amounts loaded onto the gels, the absence of immuno reactive spots in the control lead us to conclude that the immuno-reactivity was not due to non-specific cross reactivity of the antiserum (Figure 1). As the ECL images were very similar but the number of immuno-reactive spots was increased at $24 \mathrm{~h}$, we decided to pursue the subsequent analyses using the liver recovered from this rat. All of the immuno-reactive spots were estimated to be within the isoelectric point range 5-7. This was further confirmed by 2D Western blotting of total liver homogenate after isoelectric focusing on 4-7 IPG strips (data not shown). Preliminary attempts to identify the modified proteins using on-membrane digestion, nLC-ESIMS/MS and data base 
searching turned out to be complicated by the fact that the protein spots were highly heterogeneous because of incomplete protein separation (data not shown). Therefore, to improve the electrophoretic separation of the proteins and to increase the likelihood of detecting most proteins potentially adducted with TA, we took advantage of two sample purification steps. Firstly, total liver homogenates were subjected to rough pre-fractioning with ultra-centrifugation. This step resulted in four major fractions (I-IV). Secondly, the proteins were separated in the first dimension using IPG strips with a narrow $\mathrm{pH}$ range. An overview of the strategy used throughout this work is shown in figure 2 . The four fractions, obtained after ultracentrifugation were subjected to isoelectric focusing using 5.5-6.7 immobiline strips, and subsequently proteins were resolved on $8-16 \%$ mini gradient gels. Following blotting onto PVDF membranes, TA adducted proteins were visualized by ECL as shown in figure 3. Comparison of the ECL revealed relatively similar images for the fractions with several overlapping spots. This indicates that either the immuno-reactive proteins are dispersed in several cellular locations and/or the separation capacity of ultracentrifugation, as expected, could be limited. The number of most abundant and reproducibly detected immuno-reactive spots in the four fractions ranged from 24 (fraction I), 24 (fraction II), 5 (fraction III) to 13 spots in fraction IV, with the latter enriched in soluble cytosolic proteins. No spots were observed on the corresponding control Western blots using fractionated liver homogenate from rats treated with saline (data not shown). Immuno-reactive spots from each fraction were excised from India ink stained PVDF membranes used for the Western blotting experiments and subsequently subjected to reduction, carbamidomethylation and onmembrane proteolysis with trypsin. The recovered peptides were analyzed by $\mathrm{nLC}$ - 
MS/MS and corresponding proteins were identified in the Rattus protein data base using MASCOT. A total of 66 protein spots were analyzed, all resulting in positive protein identifications despite that most of the spots were not detectable by the India ink stain. An example of nLC-MS/MS analysis of tryptic peptides from spot 14, ultra centrifugation fraction II (Figure 3C,D and table II), is shown in figure 4. A flat HPLC gradient was used to insure sufficient time to produce tandem mass spectra of all doubly and triply charged ions with intensities above background level. Nine of the peptide ions selected for tandem mass spectrometry gave adequate spectra that could be unambiguously assigned to the iota chain of proteasome endopeptidase complex (EC 3.4.25.1). The results of all protein identifications are shown in table I-IV. As can be observed in table I-IV numerous spots contained multiple proteins compromising our ability to unambiguously identify certain modified proteins. Fortunately, the same protein could be identified in multiple immuno-reactive spots helping to pin-point which protein was modified among several co-migrating proteins. The presence of a common modified protein in multiple spots, although heterogeneous, explained the immuno-reactivity. The reasons for dispersion of proteins to more than one 2D spot are multifarious including different degrees of post translational modifications like phosphorylation, presence of various isoforms and the presence of fragments due to incomplete inactivation of all proteases in the cell lysate. Furthermore, many of the proteins suggested to be modified were observed in more than one Western blot of individual ultracentrifugation fractions and co-migrated with different proteins. Since the immuno-reactivity of the spots was maintained, this confirmed their assignment as modified proteins. For example, adenosylhomocysteinase could be identified in three out of the four fractions. In fraction 
II (table II), adenosylhomocysteinase in spot 11 co migrated with a TAR DNA binding protein. However, adenosylhomocysteinase was also identified in fraction III (spot 4, table III) although it co-migrated here with alpha enolase and methionine adenosyl transferase. Finally, adenosylcysteinase was identified in three distinct immuno-reactive spots $(10,11$ and 12) obtained from the PVDF membrane used for ECL detection of fraction IV (Figure 3). In these three spots, adenosylhomocysteinase co-migrated with one, two and five other proteins. Obviously, it cannot be ruled out that several immunoreactive proteins co-migrated as shown in Fraction IV spot 12, which compromised the assignment of the immuno-reactivity. Six proteins were identified in spot 12 with 3 to 22 assigned tandem mass spectra and total Mowse scores ranging from 62 to 452 . Since fumarylacetoacetase was identified unaccompanied in spot 13 and is present in spot 12 , together with adenosylhomocysteinase it may be a candidate for the immuno-reactivity. Although it cannot be excluded, it is uncertain as to whether beta-alanine synthethase and 4-hydroxyphenylpyruvate dioxygenase are candidates because they constantly comigrated with other highly potential immuno-reactive candidates (Table I, spot 9 and 10, Table II, spot 17, Table IV spot 11 and 12). Interpretation of collective data from the analyses of four fractions using the procedure described above resulted in a list of 15 candidate proteins shown in Table V that are likely to be modified by TA metabolites. Although rat albumin was found in most of the fractions and was identified in several of the spots, these analyses did not allow us to unambiguously conclude that rat albumin is modified by TA metabolites because the antiserum was raised against bovine albuminTA conjugates. However, the absence of spots corresponding to rat albumin on control Western blots indicates that, if present, cross reactivity is limited. Furthermore, keratins 
can easily contaminate carrier protein drug metabolite preparations. In both cases, antigen cross reactivity could not be completely eliminated, and thus these proteins were not included in table V.

\subsection{Discussion}

In the present work, we demonstrate that 2D Western blotting in direct conjunction with nLC-MS/MS can be used to identify rat liver proteins that are highly likely to be covalently modified by TA metabolites. Previously, the identification of proteins modified by drug metabolites using Western blotting was limited to in gel digestion of the proteins of interest after localisation of the spots on a 2D SDS PAGE gel using an ECL image obtained from immuno-blotting of a parallel gel. This method is useful when immuno-reactive proteins can be observed with mass spectrometry compatible gel staining methods. However, in our hands, this is not always the case rendering the location of the immuno-reactive spots very difficult due to the extensive discrepancy of ECL and gel staining images. In contrast, our method takes advantage of the fact that after on-membrane proteolysis it is possible to recover sufficient amount of peptides from the India ink stained PVDF membrane used for immuno-blotting to subsequently acquire high quality nLC-MS/MS data. Furthermore, the facility and precision by which the protein spots can be located on the PVDF membrane after superposition of the ECL image insure that the correct immuno-reactive spot is excised and the method is therefore likely to diminish faulty protein identifications. Considering the frequently high sensitivity of immuno-blotting one can not exclude that, from a mass spectrometry point of view, undetectable lower levels of immuno-reactive proteins could be present. The sensitivity of the method depends on the mass spectrometer used for analyses. With the 
instrument used in this study, the lower limit of detection was estimated from injecting a standard peptide mixture to be about 25-50 femtomol per peptide in order to obtain adequate tandem mass spectra for protein identification. Of notice, the protein amount retained on the PVDF membrane of several immuno-reactive protein spots was insufficient for visualization by India ink staining. Although this compromised the choice of an appropriate spot size to excise, the dimension of our spot picking tool corresponded well to the vast majority of spots observed on the ECL transparency. Nevertheless, it can obviously not be excluded that some of the protein heterogeneity could be due to excision of closely located neighbouring proteins. Despite that relatively few immuno-reactive spots were homogenous, the occurrence of protein isomers in several spots from identical fractions and their co-migration with different proteins in other fractions aided in determining which proteins may be responsible for the immuno-reactivity observed by ECL. Optimal separation can be obtained with longer immobiline strips and larger 2D gels, however, at the expense of a larger consumption of antibodies and ECL reagents. Furthermore, larger gels are in general more fragile and difficult to handle for the purpose of immuno blotting. In light of these considerations, we chose to use a medium size gel $(10 \times 10 \mathrm{~cm})$ compromising to some extend the protein separation. Attempts to determine which peptides, site and type of covalent modification(s) using the GPM search engine (http://rat.thegpm.org/tandem/thegpm tandem.html) and calculated molecular weights of possible metabolites were unsuccessful. This is not surprising because only a minor fraction of a target protein is probably modified [27-29]. Thus, even if present, the amount of a modified peptide may be lower than the instrumental limit of detection. If the modification is fragile, it could undergo fragmentation in the electrospray-ms interface, 
resulting in loss of further structural analysis. However, this is unlikely as covalent conjugates of both gluthathione-TA and mercaptoethanol-TA isomer metabolites were successfully analysed by ESI-MS in earlier studies $[12,16]$. Nevertheless, it cannot be excluded that modified peptides could be labile in the LC solvent resulting in loss of adducts during separation, as proposed previously [11]. In summary, 15 proteins were found to be covalently modified. Surprisingly, Cytochrome P450 2C11 was not identified despite that the protein was previously reported to be modified by a reactive intermediary of TA [13]. In this study, densiometric quantification of immuno blots showed maximum modification to occur in rats $2-4 \mathrm{~h}$ after TA ingestion, followed by a steady decline until $36 \mathrm{~h}$. The level of modification was approximately $20 \%$ of total after exposure for $24 \mathrm{~h}$, the delay time we used, before isolating the liver for 2D Western blotting and protein identification. In addition, the conditions for immuno blotting were different because we did not use any protein blocking reagents. Finally, we separated the proteins by $2 \mathrm{D}$ electrophoresis using a method not especially optimized for membrane proteins, and since CYP 2C11 likely is a membrane bound protein and therefore notoriously more difficult to handle, it may well have escaped detection. Three proteins identified, which include selenium binding protein, disulfide isomerase and Hsc73, have been shown to be common targets for other reactive drug intermediates and chemicals in previous studies. Selenium binding protein 2 was previously found to be covalently modified by the reactive intermediary N-acetyl-p-benzoquinone, a metabolite of acetaminophen [30,31], metabolites of chemicals like 3'-hydroxyacetanilide [32] and bromobenzene [33]. The function of selenium binding protein is presently unknown but it has been suggested to function as a scavenger protein involved in the cellular defence mechanism [31]. In 
contrast, the protein was recently shown to increase acetaminophen toxicity when over expressed in COS-1 cells, and thus, this subject is still controversial [34]. Because disulphide isomerase is an abundant protein involved in redox state control it is critical for maintaining apt cellular homeostasis. This protein catalyzes the rearrangement of disulphide bonds. Thus, the toxicological consequence(s) of a reactive TA intermediary may depend on the extent of modification and potential malfunction of disulphide isomerase. Similarly, this protein seems to be a common target for various reactive intermediaries including mycophenolic acid [21], naphthalene [25], halothane [35], bromobenzene [36], monocrotaline [37]. The dnaK-type molecular chaperone Hsc73, also called Hsc70 or Hspa8, was previously shown to be adducted by a reactive intermediary of naphthalene [25]. To our knowledge, the remaining 12 proteins identified have not previously been identified as targets for other reactive metabolites. Several of these proteins are enzymes that participle in metabolic (adenosine kinase, fumarylacetoacetase, ketohexokinase, triosephosphate isomerase, malate dehydrogenase) and catabolic (arginase) cellular processes. Capping protein (actin filament) is part of the cytoskeleton, whereas two proteins (senescence marker protein and superoxide dismutase) may be involved in cellular defence mechanisms. Adenosylhomocysteinase is thought to play a role in methylation via the regulation of adenosylhomocysteine. Finally, two of the targets are enzymes implicated in the cellular salvage of proteins (proteasome endopeptidase complex) and N-terminal blocked amino acids (Acy1). Future studies are required to evaluate if modification and/or collective inhibition of these enzymes either entirely or partly may cause cellular stress that together with implication of the immune 
system could explain the mechanism involved in TA adverse reactions. This will entail the development of approaches to determine quantitatively ratio of modified versus unmodified target proteins and the consequential toxicological impact when this ratio is displaced.

\section{Acknowledgements}

Funding for this study came from Université de Sherbrooke, the Fonds de La Recherche Santé du Québec (FRSQ), and the National Science and Engineering Research Council (NSERC). Richard Wagner is greatly acknowledged for his constructive comments and corrections. Finally, I (K. Klarskov) would like to thank Prof. Peter Roepstorff for his always enthusiastic contagious engagement in research, formation of students (especially me!), long exciting stories and warm friendship.

\section{References}

[1] Zimmerman, H. J. Lewis, J. H. Ishak, K. G. Maddrey, W. C. Hepatology 4 (1984) 315-323.

[2] Pohl, L. R. Satoh, H. Christ, D. D. Kenna, J. G. Annu. Rev. Pharmacol. Toxicol. 28 (1988) 367-387.

[3] Pirmohamed, M. Naisbitt, D. J. Gordon, F. Park, B. K. Toxicology 181-182 (2002) 55-63.

[4] Seguin, B. Uetrecht, J. Curr. Opin. Allergy Clin. Immunol. 3 (2003) 235-242.

[5] Uetrecht, J. Toxicology 209, (2005) 113-118.

[6] Homberg, J. C. Abuaf, N. Helmy-Khalil, S. Biour, M. et al. Hepatology 5 (1985) $722-727$.

[7] Beaune, P. H. Lecoeur, S. Bourdi, M. Gauffre, A. et al. Eur. J. Haematol. Suppl. 60 (1996) 89-92.

[8] Beaune, P. Dansette, P. M. Mansuy, D. Kiffel, L. et al. Proc. Natl. Acad. Sci. U. S. A. 84 (1987) 551-555. 
[9] Bonierbale, E. Valadon, P. Pons, C. Desfosses, B. et al. Chem. Res. Toxicol. 12 (1999) 286-296.

[10] Dansette, P. M. Amar, C. Valadon, P. Pons, C. et al. Biochem. Pharmacol. 41 (1991) 553-560.

[11] Koenigs, L. L. Peter, R. M. Hunter, A. P. Haining, R. L. et al. Biochemistry 38 (1999) 2312-2319.

[12] Belghazi, M. Jean, P. Poli, S. Schmitter, J. M. et al. Adv. Exp. Med. Biol. 500 (2001) 139-144.

[13] Robin, M. A. Maratrat, M. Le Roy, M. Le Breton, F. P. et al. J. Clin. Invest. 98 (1996) 1471-1480.

[14] Lopez-Garcia, M. P. Dansette, P. M. Coloma, J. Biochem. Pharmacol. 70 (2005) 1870-1882.

[15] Dansette, P. M. Amar, C. Smith, C. Pons, C. Mansuy, D. Biochem. Pharmacol. 39 (1990) 911-918.

[16] Valadon, P. Dansette, P. M. Girault, J. P. Amar, C. Mansuy, D. Chem. Res. Toxicol. 9 (1996) 1403-1413.

[17] Bailey, M. J. Dickinson, R. G. Chem. Biol. Interact. 145 (2003) 117-137.

[18] Castillo, M. Lam, Y. W. Dooley, M. A. Stahl, E. Smith, P. C. Clin. Pharmacol. Ther. 57 (1995) 636-644.

[19] Presle, N. Lapicque, F. Fournel-Gigleux, S. Magdalou, J. Netter, P. Drug Metab. Dispos. 24 (1996) 1050-1057.

[20] Bailey, M. J. Dickinson, R. G. Chem. Res. Toxicol. 9 (1996) 659-666.

[21] Shipkova, M. Beck, H. Voland, A. Armstrong, V. W. et al. Proteomics 4 (2004) 2728-2738.

[22] Dickinson, R. G. King, A. R. Biochem. Pharmacol. 46 (1993) 1175-1182.

[23] King, A. R. Dickinson, R. G. Biochem. Pharmacol. 45 (1993) 1043-1047.

[24] Williams, K. E. Carver, T. A. Miranda, J. J. Kautiainen, A. et al. Mol. Cell. Proteomics 1 (2002) 885-895.

[25] Isbell, M. A. Morin, D. Boland, B. Buckpitt, A. et al. Proteomics 5 (2005) 4197 4204.

[26] Methogo, R. M. Dufresne-Martin, G. Leclerc, P. Leduc, R. Klarskov, K. J. Proteome Res. 4 (2005) 2216-2224. 
[27] Volland, C. Sun, H. Dammeyer, J. Benet, L. Z. Drug Metab. Dispos. 19 (1991) 1080-1086.

[28] Bolze, S. Bromet, N. Gay-Feutry, C. Massiere, F. et al. Drug Metab. Dispos. 30 (2002) 404-413.

[29] Spahn-Langguth, H. Dahms, M. Hermening, A. Adv. Exp. Med. Biol. 387 (1996) 313-328.

[30] Pumford, N. R. Martin, B. M. Hinson, J. A. Biochem. Biophys. Res. Commun. 182 (1992) 1348-1355.

[31] Qiu, Y. Benet, L. Z. Burlingame, A. L. J. Biol. Chem. 273 (1998) 17940-17953.

[32] Myers, T. G. Dietz, E. C. Anderson, N. L. Khairallah, E. A. et al. Chem. Res. Toxicol. 8 (1995) 403-413.

[33] Manautou, J. E. Khairallah, E. A. Cohen, S. D. J. Toxicol. Environ. Health 46 (1995) 263-269.

[34] Ishida, T. Abe, M., Oguri, K. Yamada, H. Drug Metab. Pharmacokinet. 19 (2004) 290-296.

[35] Martin, J. L. Kenna, J. G. Martin, B. M. Thomassen, D. et al. Hepatology 18 (1993) 858-863.

[36] Koen, Y. M. Hanzlik, R. P. Chem. Res. Toxicol. 15 (2002) 699-706.

[37] Lame, M. W. Jones, A. D. Wilson, D. W. Segall, H. J. Proteomics 5 (2005) 43984413. 
Table I. Proteins identified in fraction I.

\begin{tabular}{|c|c|c|c|c|c|}
\hline spot $^{a}$ & Protein ID & $\begin{array}{c}\mathrm{Mr} \\
\text { weight }^{\mathrm{b}}\end{array}$ & $\mathbf{p l}^{\mathbf{b}}$ & $\begin{array}{l}\text { Mowse } \\
\text { score } \\
\end{array}$ & $\begin{array}{l}\text { peptides } \\
\text { Assigned }^{\mathrm{c}}\end{array}$ \\
\hline \multirow[t]{2}{*}{1} & Q5U3X3_RAT Albumin & 70710 & 6,1 & 337 & 14 \\
\hline & Q5BKB4_RAT Hemopexin & 52060 & 7,6 & 154 & 10 \\
\hline \multirow[t]{2}{*}{2} & ABRTS serum albumin precursor & 70670 & 6,1 & 692 & 26 \\
\hline & Q5BKB4_RAT Hemopexin & 52060 & 7,6 & 163 & 9 \\
\hline \multirow[t]{3}{*}{3} & ABRTS serum albumin precursor & 70670 & 6,1 & 219 & 14 \\
\hline & S21089 alpha-1-microglobulin/inter-alpha-trypsin inhibitor light chain & 39738 & 5,8 & 196 & 8 \\
\hline & Q66HD0_RAT Tumor rejection antigen gp96 (Predicted) & 74390 & 5 & 50 & 2 \\
\hline \multirow[t]{2}{*}{4} & AAH62393 BC062393 NID protein disulfide isomerase associated 3 & 57044 & 5.9 & 877 & 30 \\
\hline & ABRTS serum albumin precursor & 70670 & 6,1 & 236 & 12 \\
\hline \multirow[t]{4}{*}{5} & ABRTS serum albumin precursor & 68674 & 6,1 & 262 & 7 \\
\hline & Q8VIF7_RAT Selenium binding protein 2 & 53069 & 6,1 & 171 & 8 \\
\hline & ABRTS serum albumin precursor & 70670 & 6,1 & 115 & 6 \\
\hline & AAF43598 AF170918 NID & 54530 & 6,6 & 95 & 3 \\
\hline \multirow[t]{3}{*}{6} & Q8VIF7_RAT Selenium binding protein 2 & 53069 & 6,1 & 270 & 9 \\
\hline & AAF43598 4-trimethylaminobutyraldehyde dehydrogenase & 54530 & 6,6 & 131 & 7 \\
\hline & Q5XIM9_RAT Chaperonin containing TCP1, subunit 2 (Beta).- & 57764 & 6 & 90 & 4 \\
\hline 7 & Q6AYS7_RAT Acy1 protein & 46060 & 6 & 186 & 13 \\
\hline \multirow[t]{2}{*}{8} & A49098 N-hydroxyarylamine sulfotransferase, HAST-I & 35855 & 6,1 & 83 & 6 \\
\hline & MDHC_RAT Malate dehydrogenase, cytoplasmic (EC 1.1.1.37) & 36500 & 6,2 & 36 & 3 \\
\hline \multirow[t]{2}{*}{9} & S27881 beta-alanine synthase & 44584 & 6,5 & 146 & 9 \\
\hline & 1D3VA arginase (EC 3.5.3.1), chain A & 33423 & 6,6 & 61 & 2 \\
\hline \multirow[t]{5}{*}{10} & S27881 beta-alanine synthase & 44584 & 6,5 & 317 & 14 \\
\hline & JH0467 fumarylacetoacetase (EC 3.7.1.2) & 33423 & 6,6 & 212 & 7 \\
\hline & A54756 isocitrate dehydrogenase (NADP) (EC 1.1.1.42), & 47047 & 6,5 & 79 & 3 \\
\hline & AJRTQ glutamate-ammonia ligase (EC 6.3.1.2) & 42982 & 6,6 & 49 & 3 \\
\hline & Q2IBC6_RAT Caveolin 1 & 20710 & 5,7 & 35 & 2 \\
\hline \multirow[t]{3}{*}{11} & 1D3VA arginase (EC 3.5.3.1), chain A - rat & 33423 & 6,6 & 219 & 8 \\
\hline & S15835 3-oxo-5beta-steroid 4-dehydrogenase (EC 1.3.99.6) - rat & 37639 & 6,2 & 176 & 10 \\
\hline & PPID_RAT 40 kDa peptidyl-prolyl cis-trans isomerase (EC 5.2.1.8) & 41008 & 6,7 & 128 & 5 \\
\hline \multirow[t]{2}{*}{12} & Q5EBB4_RAT Haptoglobin.- Rattus norvegicus & 39052 & 6,1 & 312 & 14 \\
\hline & Q497B0_RAT Nitrilase family, member 2 & 31024 & 6,9 & 45 & 3 \\
\hline 13 & GBLP_BOVIN Guanine nucleotide-binding protein subunit beta 2 -like 1 & 35380 & 7,6 & 306 & 11 \\
\hline
\end{tabular}




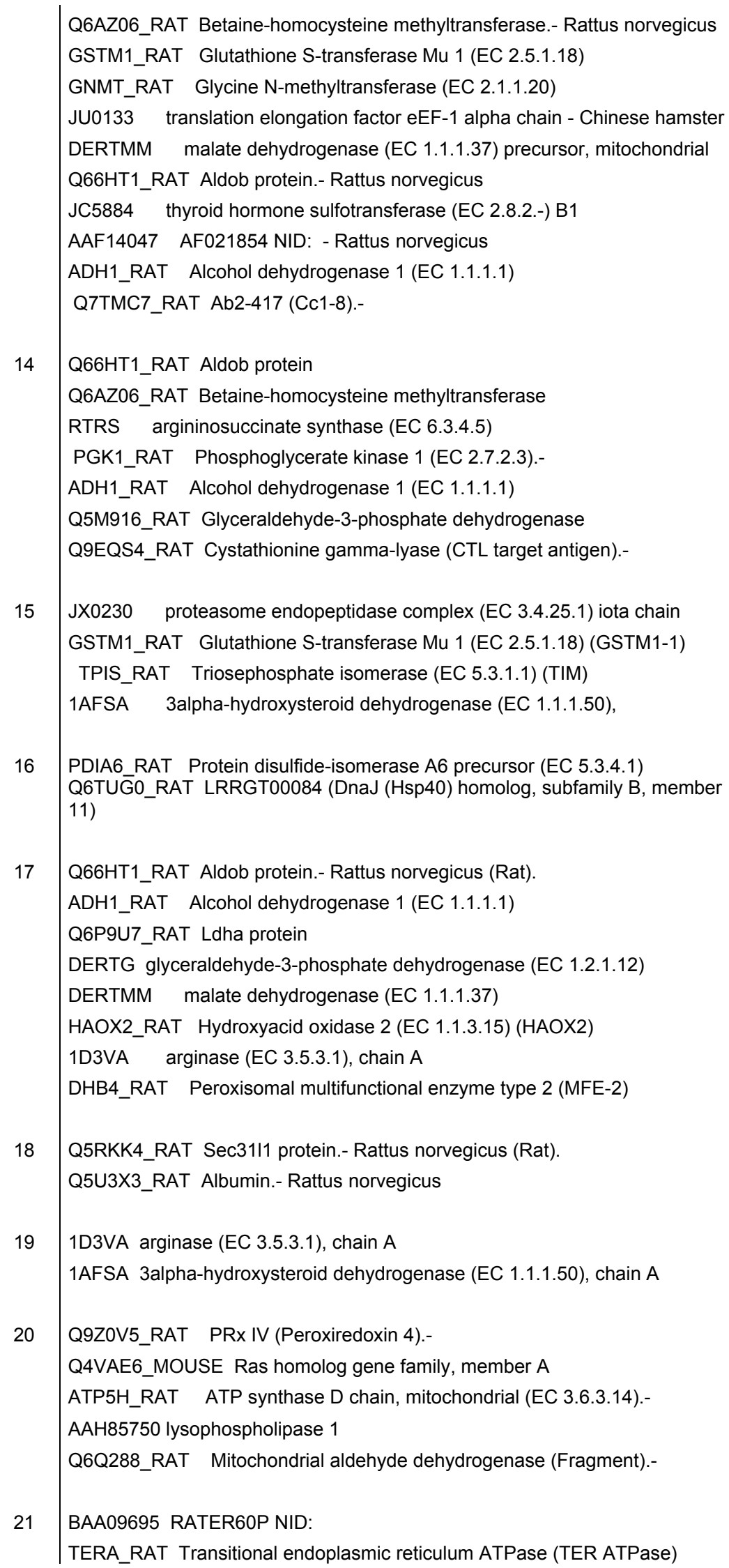




\begin{tabular}{|c|c|c|c|c|c|}
\hline \multirow[t]{5}{*}{22} & Q5U3X3_RAT Albumin.- Rattus norvegicus (Rat). & 70710 & 6,1 & 382 & 13 \\
\hline & Q642G1_RAT Adenosine kinase.- Rattus norvegicus & 40449 & 5,8 & 230 & 11 \\
\hline & Q6Q289_RAT Mitochondrial aldehyde dehydrogenase (Fragment).- & 56078 & 7,6 & 130 & 7 \\
\hline & A28807 protein disulfide-isomerase (EC 5.3.4.1) & 57044 & 6,4 & 103 & 6 \\
\hline & AAF43598 4-trimethylaminobutyraldehyde dehydrogenase & 54530 & 6,6 & 68 & 3 \\
\hline \multirow[t]{3}{*}{23} & Q5BKB7_RAT Ftcd protein & 59504 & 5,8 & 649 & 24 \\
\hline & AAH62393 protein disulfide isomerase associated 3 & 57044 & 5,9 & 400 & 17 \\
\hline & ABRTS serum albumin precursor & 70670 & 6,1 & 45 & 2 \\
\hline 24 & Q3T1K5_RAT Capping protein (Actin filament) & 33118 & 5,6 & 120 & 4 \\
\hline
\end{tabular}

a. Spots are from the India ink stained 2D immuno-blot shown in figure 3A.

b. Molecular weight and isoelectric point was obtained from the Mascot search engine.

c. Number of peptides assigned to the protein entry. 
Table II. Proteins identified in fraction II.

\begin{tabular}{|c|c|c|c|c|c|}
\hline spot $^{a}$ & Protein ID & $\begin{array}{c}\text { Mr } \\
\text { weight }^{b}\end{array}$ & $\mathrm{pl}^{\mathbf{b}}$ & $\begin{array}{c}\text { Mowse } \\
\text { score }\end{array}$ & $\begin{array}{l}\text { peptides } \\
\text { assigned }^{\mathrm{c}}\end{array}$ \\
\hline \multirow[t]{4}{*}{1} & JC4853 dnaK-type molecular chaperone hsc73 - mouse & 71055 & 5,4 & 289 & 11 \\
\hline & Q5BKB4_RAT Hemopexin.- Rattus norvegicus (Rat). & 52060 & 7,6 & 134 & 10 \\
\hline & Q5U3X3_RAT Albumin.- Rattus norvegicus & 70710 & 6,1 & 119 & 5 \\
\hline & Q6IMF3_RAT Type II keratin Kb1.- Rattus norvegicus & 65190 & 8 & 55 & 3 \\
\hline \multirow[t]{3}{*}{2} & Q5U3X3_RAT Albumin.- & 70710 & 6,1 & 373 & 14 \\
\hline & JC4853 dnaK-type molecular chaperone hsc73 - mouse & 71055 & 5,4 & 118 & 6 \\
\hline & Q5BKB4_RAT Hemopexin.- & 52060 & 7,6 & 49 & 4 \\
\hline 3 & Q5U3X3_RAT Albumin.- Rattus norvegicus & 70710 & 6,1 & 256 & 8 \\
\hline \multirow[t]{3}{*}{4} & AAH62393 protein disulfide isomerase associated 3 & 57044 & 5,9 & 371 & 16 \\
\hline & Q5U3X3_RAT Albumin.- & 70710 & 6,1 & 309 & 14 \\
\hline & AAF43598 AF170918 NID & 54530 & 6,6 & 68 & 2 \\
\hline \multirow[t]{3}{*}{5} & AAF43598 4-trimethylaminobutyraldehyde dehydrogenase & 54530 & 6,6 & 115 & 4 \\
\hline & A28807 protein disulfide-isomerase (EC 5.3.4.1) & 57044 & 6,4 & 112 & 6 \\
\hline & Q5BKB7_RAT Ftcd protein & 59504 & 5,8 & 66 & 3 \\
\hline \multirow[t]{4}{*}{6} & ENOA_RAT Alpha-enolase (EC 4.2.1.11) & 46967 & 6,2 & 191 & 8 \\
\hline & Q8VIF7_RAT Selenium binding protein 2.- & 52498 & 6,1 & 187 & 8 \\
\hline & AAF43598 AF170918 NID: & 53618 & 6,6 & 163 & 5 \\
\hline & Q5XIM9_RAT Chaperonin containing TCP1, subunit 2 (Beta).- & 57422 & 6 & 137 & 6 \\
\hline 7 & ATCHB actin beta - chicken & 42052 & 5,3 & 173 & 6 \\
\hline 8 & Q6AYS7_RAT Acy1 protein.- Rattus norvegicus (Rat). & 46060 & 6 & 163 & 8 \\
\hline 9 & S34588 senescence marker protein SMP-30 & 33938 & 5,4 & 134 & 4 \\
\hline \multirow[t]{2}{*}{10} & R5RT10 acidic ribosomal protein P0, cytosolic [similarity] & 34350 & 5,9 & 107 & 3 \\
\hline & MDHC_RAT Malate dehydrogenase, cytoplasmic (EC 1.1.1.37) & 36500 & 6,2 & 68 & 2 \\
\hline \multirow[t]{2}{*}{11} & SAHH_RAT Adenosylhomocysteinase (EC 3.3.1.1) & 47889 & 6,1 & 348 & 12 \\
\hline & Q5XID2_RAT TAR DNA binding protein (Predicted).- & 32526 & 6,5 & 59 & 4 \\
\hline \multirow[t]{2}{*}{12} & Q5BKC2_RAT Endoplasmic retuclum protein 29 & 28614 & 6,2 & 76 & 4 \\
\hline & S40468 proteasome subunit RC10-li & 23235 & 6,2 & 70 & 3 \\
\hline 13 & S32426 ketohexokinase (EC 2.7.1.3) & 33299 & 6,2 & 465 & 14 \\
\hline 14 & JX0230 proteasome endopeptidase complex (EC 3.4.25.1) & 27838 & 6,3 & 274 & 9 \\
\hline
\end{tabular}




\begin{tabular}{|c|c|c|c|c|c|}
\hline 15 & TPIS_RAT Triosephosphate isomerase (EC 5.3.1.1) (TIM) & 27286 & 6,5 & 85 & 3 \\
\hline 16 & HPPD_RAT 4-hydroxyphenylpyruvate dioxygenase (EC 1.13.11.27) & 45181 & 6,3 & 217 & 10 \\
\hline \multirow[t]{2}{*}{17} & S27881 beta-alanine synthase & 44584 & 6,5 & 247 & 11 \\
\hline & $\mathrm{JH} 0467$ fumarylacetoacetase (EC 3.7.1.2) & 46231 & 6,7 & 42 & 2 \\
\hline \multirow[t]{2}{*}{18} & 1AFSA 3alpha-hydroxysteroid dehydrogenase (EC 1.1.1.50), & 37172 & 7,3 & 202 & 7 \\
\hline & Q6IMF3_RAT Type II keratin Kb1.- Rattus norvegicus (Rat). & 65190 & 8 & 139 & 4 \\
\hline 19 & SODC_RAT Superoxide dismutase [Cu-Zn] (EC 1.15.1.1).- & 15492 & 5,9 & 281 & 8 \\
\hline \multirow[t]{4}{*}{20} & $\begin{array}{l}\text { CAH3_RAT Carbonic anhydrase } 3 \text { (EC 4.2.1.1) (Carbonic anhydrase } \\
\text { III) }\end{array}$ & 29567 & 7 & 196 & 10 \\
\hline & JC1132 phosphoglycerate mutase (EC 5.4.2.1) B chain & 28928 & 6,7 & 100 & 5 \\
\hline & Q4V8M8_RAT Hagh protein (Fragment).- Rattus norvegicus & 34036 & 7,8 & 87 & 5 \\
\hline & TPIS_RAT Triosephosphate isomerase (EC 5.3.1.1) & 27286 & 6,5 & 40 & 2 \\
\hline \multirow[t]{2}{*}{21} & PSA2_RAT Proteasome subunit alpha type 2 (EC 3.4.25.1) & 25893 & 7,1 & 270 & 9 \\
\hline & $\begin{array}{l}\text { GSTM2_RAT Glutathione S-transferase Mu } 2 \text { (EC 2.5.1.18) (GSTM2- } \\
\text { 2) }\end{array}$ & 25726 & 7,3 & 105 & 4 \\
\hline \multirow[t]{2}{*}{22} & TPIS_RAT Triosephosphate isomerase (EC 5.3.1.1) & 27286 & 6,5 & 82 & 3 \\
\hline & Q6IMF3_RAT Type II keratin Kb1.- Rattus norvegicus & & & & \\
\hline 23 & Q4V8I9_RAT UDP-glucose pyrophosphorylase 2.- & 57159 & 7,2 & 67 & 3 \\
\hline \multirow[t]{4}{*}{24} & GSTM1_RAT Glutathione S-transferase Mu 1 (EC 2.5.1.18) & 25937 & 8,4 & 117 & 4 \\
\hline & Q6IMF3_RAT Type II keratin Kb1.- Rattus norvegicus & 65190 & 8 & 110 & 4 \\
\hline & Q6IFU8_RAT Type I keratin KA17.- Rattus norvegicus (Rat). & 48378 & 5 & 78 & 3 \\
\hline & K2C8_RAT Keratin, type II cytoskeletal 8 (Cytokeratin-8) & 53854 & 5,8 & 78 & 3 \\
\hline
\end{tabular}

a. Spots are from the India ink stained 2D immuno-blot shown in figure 3C.

b. Molecular weight and isoelectric point was obtained from the Mascot search engine.

c. Number of peptides assigned to the protein entry. 
Table III. Proteins identified in fraction III.

\begin{tabular}{|c|c|c|c|c|c|}
\hline $\operatorname{spot}^{a}$ & Protein ID & $\begin{array}{c}\mathrm{Mr} \\
\text { weight }\end{array}$ & $\mathbf{p l}^{\mathbf{b}}$ & $\begin{array}{c}\text { Mowse } \\
\text { score }\end{array}$ & $\begin{array}{l}\text { peptides } \\
\text { assigned }^{c}\end{array}$ \\
\hline \multirow[t]{2}{*}{1} & GRP75_R Stress-70 protein & 74086 & 6 & 460 & 12 \\
\hline & JC4853 dnaK-type molecular chaperone hsc73 & 71055 & 5,4 & 255 & 10 \\
\hline 2 & Q8VIF7_RAT Selenium binding protein 2 & 53069 & 6,1 & 92 & 7 \\
\hline 3 & Q642G1_RAT Adenosine kinase.- Rattus norvegicus (Rat). & 40449 & 5,8 & 146 & 5 \\
\hline \multirow[t]{3}{*}{4} & ENOA_RAT Alpha-enolase (EC 4.2.1.11) & 47309 & 6,2 & 238 & 9 \\
\hline & SAHH_RAT Adenosylhomocysteinase (EC 3.3.1.1) & 47889 & 6,1 & 107 & 5 \\
\hline & S06114 methionine adenosyltransferase (EC 2.5.1.6) & 44240 & 5,6 & 51 & 3 \\
\hline 5 & $\begin{array}{l}\text { MDHC_RAT Malate dehydrogenase, cytoplasmic (EC } \\
\text { 1.1.1.37) }\end{array}$ & 36500 & 6,2 & 198 & 11 \\
\hline
\end{tabular}

a. Spots are from the India ink stained 2D immuno-blot shown in figure 3E.

b. Molecular weight and isoelectric point was obtained from the Mascot search engine.

c. Number of peptides assigned to the protein entry. 
Table IV. Proteins identified in fraction IV.

\begin{tabular}{|c|c|c|c|c|c|}
\hline spot $^{a}$ & Protein ID & $\begin{array}{c}\mathrm{Mr} \\
\text { weight }^{\mathrm{b}}\end{array}$ & $\mathrm{pl}^{\mathrm{b}}$ & $\begin{array}{l}\text { Mowse } \\
\text { score }\end{array}$ & $\begin{array}{l}\text { peptides } \\
\text { assigned }^{c}\end{array}$ \\
\hline \multirow[t]{2}{*}{1} & Q9JKB7_RAT Guanine deaminase & 51439 & 5,5 & 47 & 3 \\
\hline & I59346 glutathione synthase (EC 6.3.2.3 & 52597 & 5,5 & 47 & 2 \\
\hline \multirow[t]{3}{*}{2} & DOPD_D-dopachrome decarboxylase (EC 4.1.1.84) & 13108 & 6,2 & 208 & 9 \\
\hline & RJRTO retinol-binding protein, cellular & 15995 & 5,1 & 84 & 2 \\
\hline & FABPB_Fatty acid-binding protein, brain (B-FABP) & 15008 & 5,5 & 71 & 3 \\
\hline \multirow[t]{2}{*}{3} & Q5U3X3_RAT Albumin.- & 70710 & 6,1 & 396 & 15 \\
\hline & Q5BKB4_RAT Hemopexin.- & 52060 & 7,6 & 110 & 7 \\
\hline 4 & Q6IMF3_RAT Type II keratin Kb1.- Rattus norvegicus & 65190 & 8 & 131 & 5 \\
\hline 5 & ABRTS serum albumin precursor & 70670 & 6,1 & 831 & 31 \\
\hline 6 & $\begin{array}{l}\text { Q5U3X3_RAT Albumin } \\
\text { DDAH1_NG,NG-dimethylarginine } \\
\text { dimethylaminohydrolase1(EC3.5.3.18) }\end{array}$ & $\begin{array}{l}70710 \\
31674\end{array}$ & $\begin{array}{l}6,1 \\
5,8\end{array}$ & $\begin{array}{l}100 \\
95\end{array}$ & $\begin{array}{l}2 \\
3\end{array}$ \\
\hline \multirow[t]{5}{*}{7} & Q8VIF7_RAT Selenium binding protein 2 & 53069 & 6,1 & 197 & 9 \\
\hline & AAF43598 AF170918 NID & 54530 & 6,6 & 193 & 8 \\
\hline & ENOA_RAT Alpha-enolase (EC 4.2.1.11) & 47309 & 6,2 & 106 & 6 \\
\hline & ABRTS serum albumin precursor & 70670 & 6,1 & 104 & 3 \\
\hline & Q6Q288_RAT Mitochondrial aldehyde dehydrogenase (Fragment).- & 56078 & 7,6 & 90 & 3 \\
\hline 8 & Q642G1_RAT Adenosine kinase.- Rattus norvegicus (Rat). & 40449 & 5,8 & 365 & 18 \\
\hline \multirow[t]{3}{*}{9} & Q5U3X3_RAT Albumin.- Rattus norvegicus & 70710 & 6,1 & 198 & 5 \\
\hline & Q6Q290_RAT Mitochondrial aldehyde dehydrogenase (Fragment).- & 56051 & 6,4 & 65 & 5 \\
\hline & A28807 Protein disulfide-isomerase & 57010 & 5,9 & 54 & 4 \\
\hline \multirow[t]{3}{*}{10} & Q6AYS7_RAT Acy1 protein.- Rattus norvegicus (Rat). & 46060 & 6 & 301 & 16 \\
\hline & SAHH_RAT Adenosylhomocysteinase (EC 3.3.1.1) & 47889 & 6,1 & 203 & 6 \\
\hline & AAF43598 AF170918 NID & 54530 & 6,6 & 152 & 7 \\
\hline \multirow[t]{2}{*}{11} & SAHH_RAT Adenosylhomocysteinase (EC 3.3.1.1) & 47889 & 6,1 & 675 & 26 \\
\hline & HPPD_RAT 4-hydroxyphenylpyruvate dioxygenase (EC 1.13.11.27) & 45181 & 6,3 & 51 & 5 \\
\hline \multirow[t]{6}{*}{12} & HPPD_RAT 4-hydroxyphenylpyruvate dioxygenase (EC 1.13.11.27) & 45181 & 6,3 & 452 & 22 \\
\hline & S27881 beta-alanine synthase & 44584 & 6,5 & 112 & 6 \\
\hline & AAL61609 AF393243 NID: & 41771 & 6,2 & 156 & 7 \\
\hline & JH0467 fumarylacetoacetase (EC 3.7.1.2) & 46231 & 6,7 & 110 & 5 \\
\hline & Q68FT9_RAT Selenocysteine lyase & 47682 & 6,2 & 104 & 4 \\
\hline & SAHH_RAT Adenosylhomocysteinase (EC 3.3.1.1) & 47889 & 6,1 & 62 & 3 \\
\hline
\end{tabular}


\begin{tabular}{|l|ll}
13 & $\mathrm{JH} 0467$ & fumarylacetoacetase (EC 3.7.1.2)
\end{tabular} \begin{tabular}{l|l|l}
46231 & 6,7 & 188
\end{tabular}

a. Spots are from the India ink stained 2D immuno-blot shown in figure 3G.

b. Molecular weight and isoelectric point was obtained from the Mascot search engine.

c. Number of peptides assigned to the protein entry

Table V. Identified protein targets likely to be modified by reactive intermediates of TA.

\begin{tabular}{|l|c|c|}
\hline \multicolumn{1}{|c|}{ Protein ID } & $\begin{array}{c}\text { Mr } \\
\text { weight }^{\mathbf{a}}\end{array}$ & $\mathbf{~ p l}^{\mathbf{a}}$ \\
\hline Selenium binding protein 2 & 53069 & 6,1 \\
senescence marker protein SMP-30 & 33938 & 5,4 \\
Adenosin kinase & 40449 & 5,8 \\
Acy1 protein & 46060 & 6,0 \\
Adenosylhomocysteinase & 47889 & 6,1 \\
Capping protein (Actin filament) & 33118 & 5,6 \\
ENOA_RAT Alpha-enolase (EC 4.2.1.11) & 47309 & 6,2 \\
Fumarylacetoacetase & 33423 & 6,6 \\
Arginase chain A & 35122 & 6,6 \\
Ketohexokinase & 33299 & 6,2 \\
Proteasome endopeptidase complex & 27838 & 6,3 \\
Triosephosphate isomerase & 27286 & 6,5 \\
Superoxide dismutase & 15492 & 5,9 \\
Malate dehydrogenase & 36500 & 6,2 \\
\hline
\end{tabular}

a. Molecular weight and isoelectric point was obtained from the Mascot search program. 
$\mathrm{pH} 3$

$\mathrm{pH} 3$
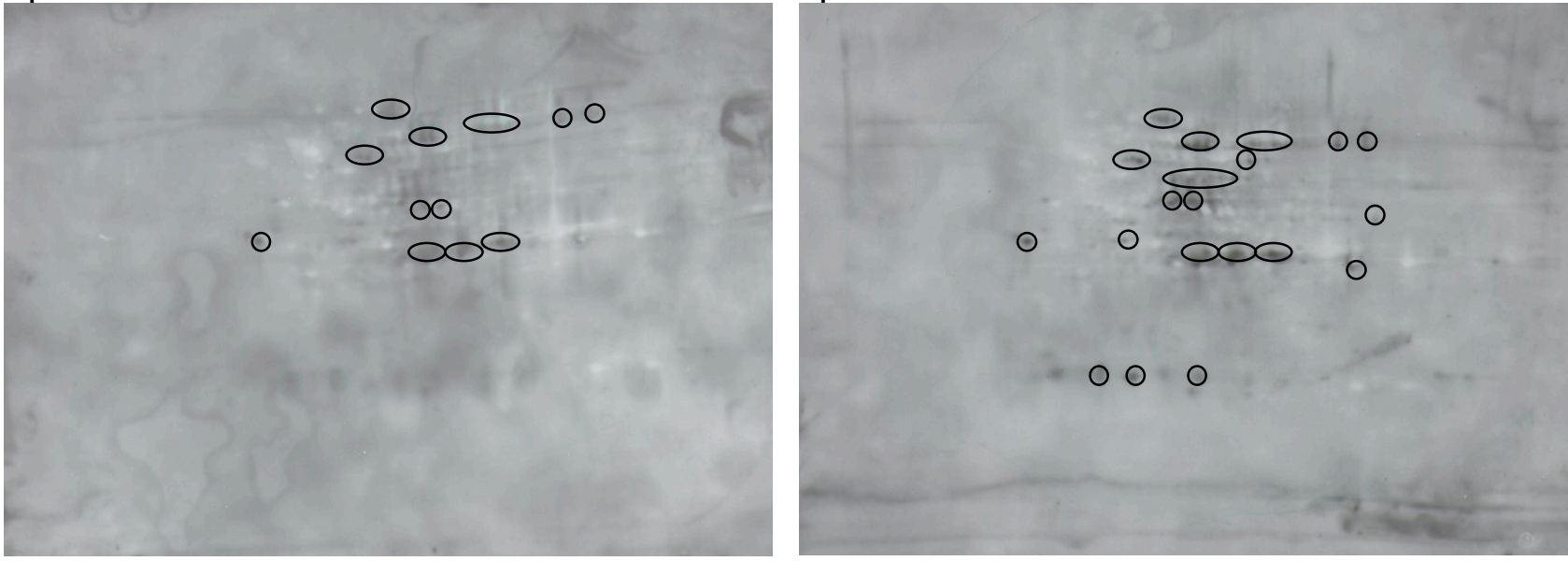

A

B 
Figure 2.

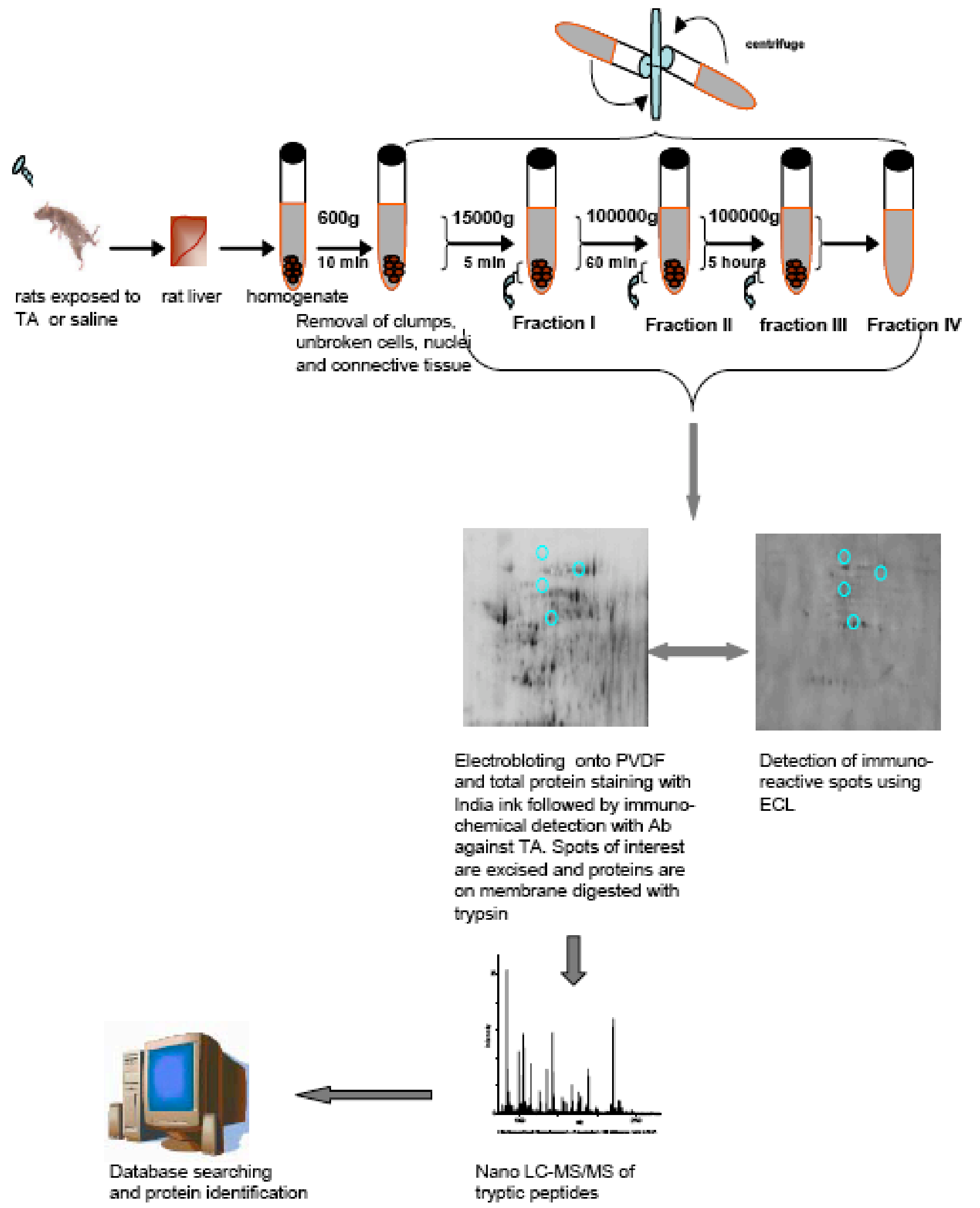




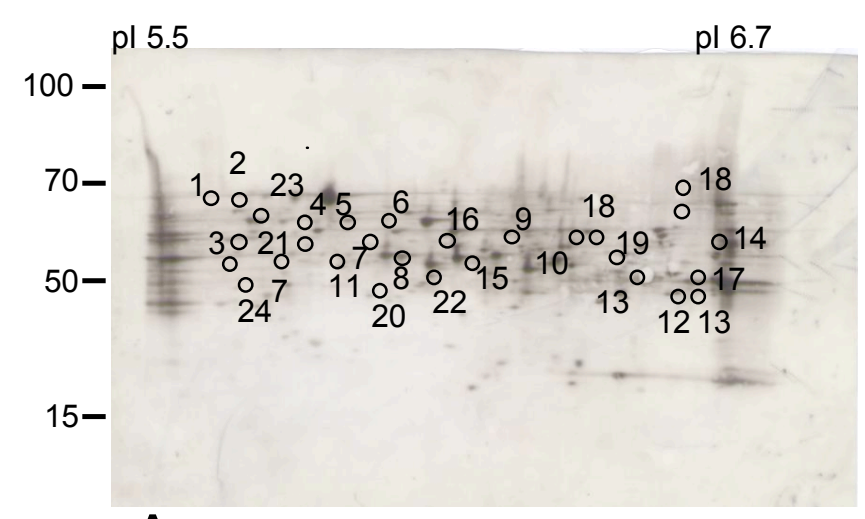

A
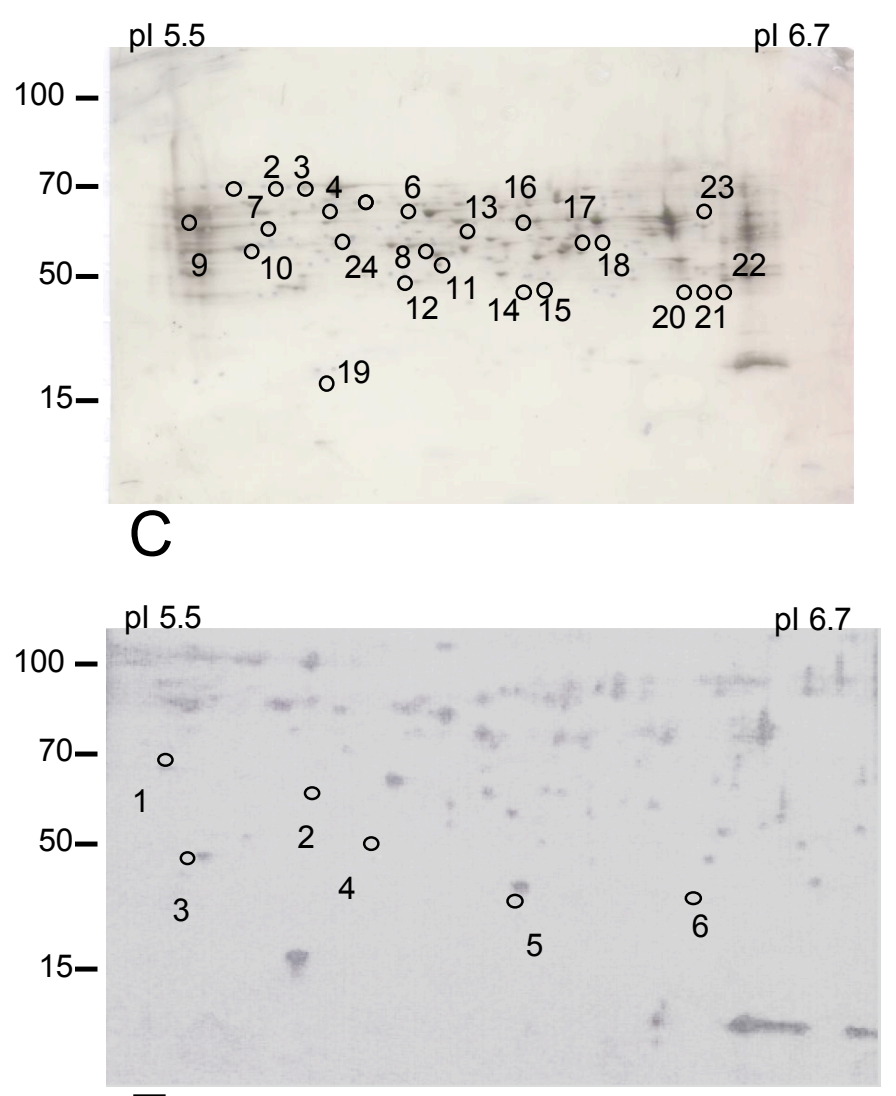

E

pl 5.5

pl 6.7

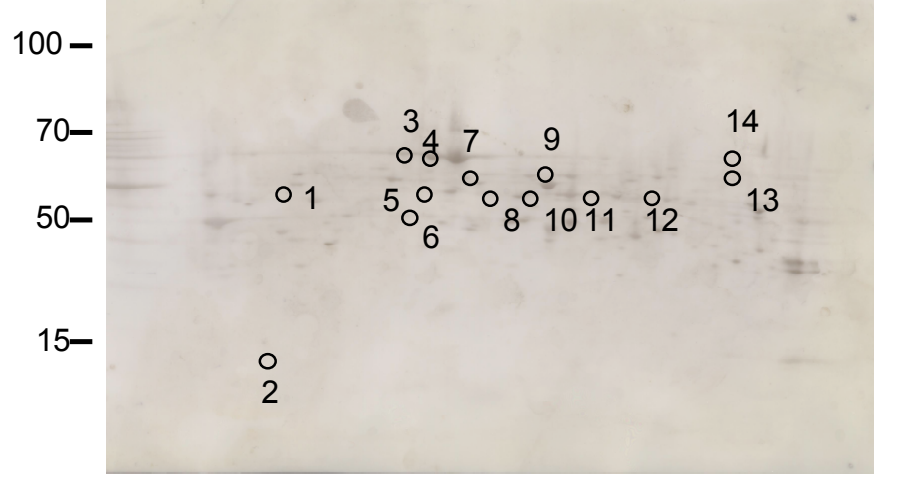

$G$

Figure 3 pl 5.5

pl 6.7

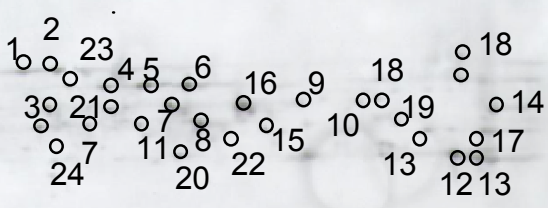

\section{B}

pl 5.5

pl 6.7

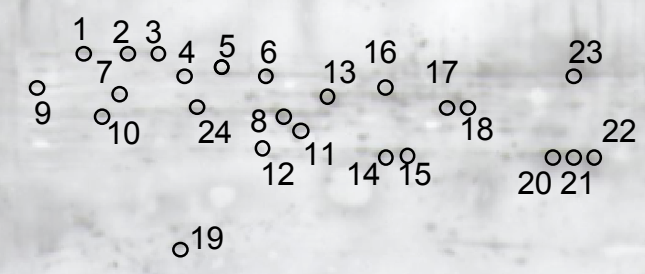

D

pl 5.5

pl 6.7

\section{F}

pl 5.5

pl 6.7

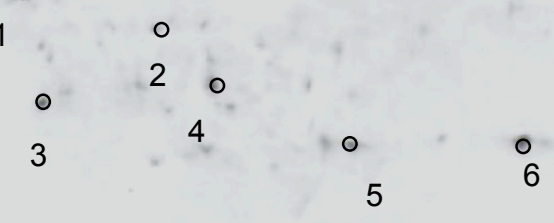

5

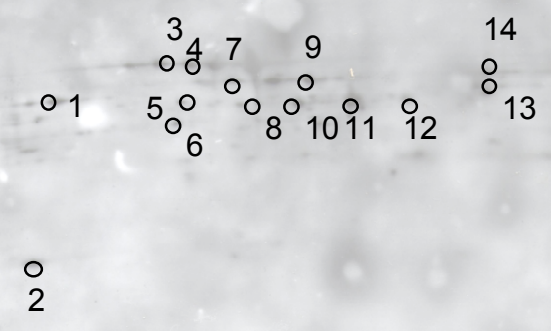

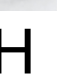


Figure 4.
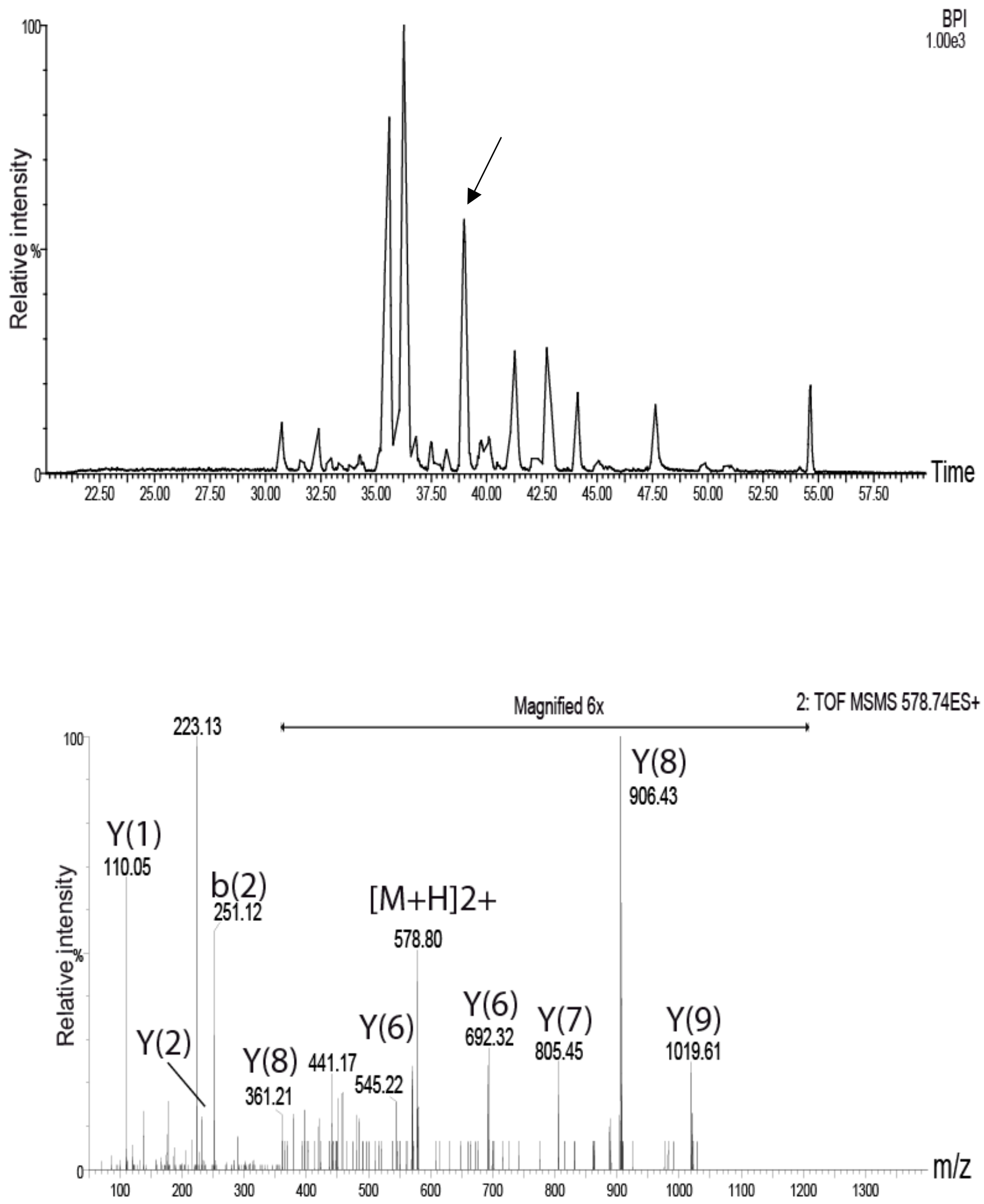